\title{
THEORETICAL AND EXPERIMENTAL INVESTIGATION OF PYRIDYL- THIOUREA DERIVATIVES AS IONOPHORES FOR Cu(II) ION DETECTION
}

\section{(Kajian Teori dan Eksperimen bagi Terbitan -Terbitan Piridil-Tiourea Sebagai Ionofor untuk Pengesanan Ion $\mathrm{Cu}(\mathrm{II}))$}

\author{
Wan M. Khairul ${ }^{1 *}$, Mohd Faizuddin Abu Hasan ${ }^{1}$, Adibah Izzati Daud ${ }^{1,3}$, \\ Hafiza Mohamed Zuki ${ }^{2}$, Ku Halim Ku bulat ${ }^{1}$, Maisara Abdul Kadir ${ }^{1}$ \\ ${ }^{1}$ School of Fundamental Science \\ ${ }^{2}$ School of Marine Science and Environment \\ Universiti Malaysia Terengganu, 21030 Kuala Terengganu, Terengganu, Malaysia \\ ${ }^{3}$ Faculty of Engineering Technology, \\ Universiti Malaysia Perlis (UniMAP), \\ Aras 1, Blok S2, Kampus UniCITI Alam, Sungai Chuchuh, 02100 Padang Besar, Perlis, Malaysia \\ *Corresponding author: wmkhairul@umt.edu.my
}

Received: 5 November 2015; Accepted: 27 December 2015

\begin{abstract}
Copper (II) ion chemical sensors based on pyridine-thiourea derivatives; $N$-pyridyl- $N$ '-(biphenyl-4-carbonyl)thiourea (L1), and $N$-pyridyl- $N$ '-(3,5-dimethyoxybenzoyl)thiourea (L2) were synthesised, characterised, and studied as ionophores in the form of thin-films PVC membranes. The ionophores exhibited good responses towards copper (II) ion over the concentration range of 2 $\mathrm{x} 10^{-4}$ to $10 \times 10^{-4} \mathrm{M}$ with a limit of detection $1.34 \times 10^{-5}$ to $1.48 \times 10^{-5} \mathrm{M}$. The proposed sensors $\mathbf{L 1}$ and $\mathbf{L 2}$ revealed good performance in term of reproducibility and regeneration of the ionophores with low relative standard deviation (RSD) values $4.17 \%$ and $2.74 \%$ respectively. Besides, quantum chemical calculation performed using Gaussian 09 program indicated the oxygen $(\mathrm{O})$ atom from carbonyl moiety $(\mathrm{C}=\mathrm{O})$ was the most favourite reactive site and mainly responsible for ionophore- $\mathrm{Cu}(\mathrm{II})$ interaction. The obtained data revealed pyridine-thiourea derivatives offered great potential as ionophore for the detection of $\mathrm{Cu}$ (II) ion.
\end{abstract}

Keywords: pyridine, thiourea, metal sensor, density functional theory, spectroscopic

\section{Abstrak}

Pengesan kimia bagi ion kuprum (II) berasaskan terbitan piridil-tiourea; $N$-piridil- $N$ '-(bifenil-4-karbonil)tiourea (L1), and $N$ piridil- $N$ '-(3,5-dimetoksibenzoil)tiourea (L2) telah disintesis, dicirikan, dan dikaji sebagai ionofor dalam bentuk membranmembran PVC filem nipis. Ionofor - ionofor tersebut menunjukkan tindak balas yang baik terhadap ion kuprum (II) dalam julat kepekatan $2 \times 10^{-4}$ to $10 \times 10^{-4} \mathrm{M}$ dengan had pengesanan $1.34 \times 10^{-5}$ sehingga $1.48 \times 10^{-5} \mathrm{M}$. Pengesan L1 dan L2 yang dicadangkan ini menunjukkan prestasi yang baik dari segi kebolehkeluaran semula dan penjanaan semula bagi ionofor - ionofor tersebut dengan nilai sisihan relatif piawaian yang rendah iaitu masing - masing $4.17 \%$ dan $2.74 \%$. Selain itu, pengiraan kuantum kimia dilakukan dengan menggunakan program Gaussian 09 yang menyatakan bahawa atom oksigen (O) daripada moiti karbonil $(\mathrm{C}=\mathrm{O})$ adalah kawasan paling reaktif dan selalunya terlibat dalam interaksi ionofor-Cu (II). Data yang diperolehi menyatakan terbitan piridil-tiourea menawarkan potensi yang bagus sebagai ionofor bagi pengesanan ion $\mathrm{Cu}$ (II).

Kata kunci: piridina, tiourea, pengesan logam, teori fungsi ketumpatan, spektroskopi 
In this developing era, industrial sector has rapidly become one of the most important sectors throughout the world. Production and manufacturing sectors gradually increase the rate of pollution as a result of the industrialisation process. Undoubtedly, metal as pollutant is known to be one of the common water pollution and has emerged as a harmful pollutant due to its toxicity at low concentration. Excessive amount of heavy metals will produce various toxicological effects and danger to most living organisms including to human [1,2]. Among these, copper $(\mathrm{Cu})$ which is classified as one of the metal pollutants which known to be toxic substance at certain concentration [3, 4]. Furthermore, Aziz et al. [5] reported the maximum limit under Standard B of Malaysian-Environmental Quality Act 1974 (Sewage and Industrial Effluents) 1979 is $1.0 \mathrm{mg} / \mathrm{L}$ which eventually make the detection process of this species to be such a challenge. Generally, metal detection in water samples depends on the utilization of expensive instrumentation techniques which at certain extend, can be rather complicated and time consuming [6 - 8]. Nowadays, there is a growing interest on research directed to the precaution of environmental control and industrial processes. Therefore, chemical sensor has arisen as an ideal option due to its rapid and simple approach towards detection. Thus, we proposed to synthesise and characterise a new class of ionophores featuring multi-chelating agent of pyridyl-thiourea derivatives which were fabricated into thin-film as molecular sensor towards copper (II) ion as an analyte of choice. A series of pyridine substituted thiourea compounds with different aromatic substituents namely biphenyl and 3,5-dimethoxybenzene were synthesised as proposed metal dication sensors prior treated as chemosensor for the detection of $\mathrm{Cu}$ (II) ion in the form of thin films. Figure 1 depicts all molecular structures of ionophores synthesised in this study.

Due to electronic conjugation system, multiple donor atoms ( $\mathrm{S}, \mathrm{O}$ and $\mathrm{N})$ for complexation and ease of synthesis, thiourea moiety was chosen as material for development of potential chemical sensor. In order to enhance electronic conjugation of this system, several electron donor groups (R) were selected which expected to generate ideal flow of electrons via the progress of fair electronic conjugation in thiourea molecular framework. Besides, pyridine was introduced as substituent in this system to increase number of possible binding sites for interaction of metal ion. In order to specifically find the accurate interacting site of this molecule towards copper (II), density functional theory (DFT) calculation using Gaussian 09 was also carried out. The study on limit of detection, reproducibility and efficiency of these molecules in the form of thin films were carried out via UV-visible analysis. Result revealed that the efficiency and suitability of this system can be applied as chemical sensor for $\mathrm{Cu}^{2+}$ ion detection.

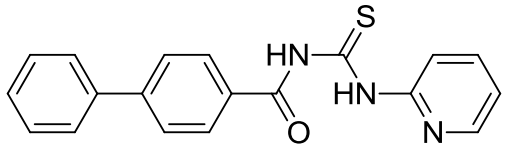

L1

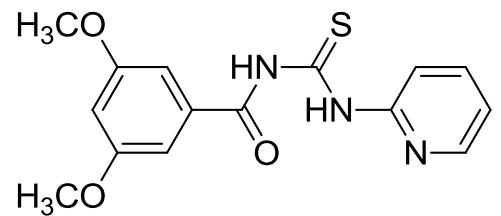

L2

Figure 1. The molecular structures of pyridine-thiourea derivatives

\section{Reagents}

Materials and Methods

The chemicals used, namely ammonium thiocyanate, 2-benzylaminopyridine, biphenyl-4-carbonyl chloride, and 3,5-dimethoxy benzoyl chloride, were purchased from Sigma-Aldrich, Merck, Acrós Organics, and R \& M Chemical. All solvents used in this study such as acetone, chloroform, dichloromethane, diethyl ether, ethyl acetate, hexane, methanol, and acetonitrile were purchased from Merck, Fisher Scientific, and R \& M Chemical. For film membrane preparation, high molecular weight poly(vinyl chloride)(PVC), sodium tetraphenyl borate, tributyl phosphate, and tetrahydrofuran (THF) were used as received from Merck.

\section{Characterisation}

Infrared (IR) spectra were recorded using FT-IR Perkin-Elmer 100 spectrophotometer within spectral range 4000$400 \mathrm{~cm}^{-1}$. CHNS microanalysis was carried out using a FLASHEA 1112 CHNS analyser for determination of 
percentage of CHNS elements presence in the synthesised compounds. NMR spectra were recorded on Bruker Avance III $400\left({ }^{1} \mathrm{H} 400.11 \mathrm{MHz},{ }^{13} \mathrm{C} 100.61 \mathrm{MHz}\right)$ using deuterated chloroform $\left(\mathrm{CDCl}_{3}\right)$ at room temperature. The interaction between ionophores and $\mathrm{Cu}^{2+}$ were investigated using UV-visible spectrophotometer Shidmazu 1601 series in $1 \mathrm{~cm}$ path length quartz cell. Thin films membranes were fabricated via SCS 6808 spin-coater at angular speed of spinning at $2500 \mathrm{rpm}$. Theoretical evaluation was carried out to predict and investigate potential interaction between the synthesised compounds and $\mathrm{Cu}^{2+}$ ion via Gaussian 09 program package. The basic set used in the theoretical simulation was based on density functional theory (DFT) calculation at B3LYP/LANL2DZ to obtain several significant structural parameters.

\section{Theoretical Evaluation on Interaction of the Pyridyl-Thiourea Compounds Towards $\mathbf{C u}($ II)}

The theoretical analysis was carried out to observe several important parameters such as interaction behaviour, binding strength and binding mode of the pyridyl-thiourea derivatives (L1 and L2) towards the tested analyte which undoubtedly contributed in sensing capability of each compound towards the studied metal ion using Gaussian 09 software. This theoretical analysis was based on DFT calculation at B3LYP/ 6-31G (d,p) for the thiourea compound and B3LYP/LANL2DZ for interaction of the synthesised compounds towards $\mathrm{Cu}$ (II) ion.

\section{Synthesis of ionophores: Synthesis of $N$-pyridyl- $N$ '-(biphenyl-4-carbonyl)thiourea (L1)}

Ammonium thiocyanate $(0.46 \mathrm{~g}, 6.00 \mathrm{mmol})$ in acetone was charged into a solution of biphenyl-4-carbonyl chloride $(1.30 \mathrm{~g}, 6.00 \mathrm{mmol})$ to yield a suspension of pale yellow solution and white precipitate after $c a .4$ hours of refluxed condition with constant stirring. The white precipitate was filtered. Then, a solution of 2-aminopyridine ( $0.56 \mathrm{~g}$, $6.00 \mathrm{mmol}$ ) in acetone was added dropwise into the pale yellow filtrate. The reaction mixture was stirred at refluxed condition for $c a$. 6 hours. After adjudged completion by TLC (ethyl acetate: hexane; 1:4), the reaction was cooled to room temperature. Subsequent to addition of three ice cubes into the yellow filtrate, pale yellow precipitate was formed and filtered. The precipitate was recrystallized from methanol to produce yellow solid of $\mathbf{L 1}$ ( $1.45 \mathrm{~g}$, 73\%). ${ }^{1} \mathrm{H}$ NMR $\left(400.11 \mathrm{MHz}, \mathrm{CDCl}_{3}\right): \delta_{\mathrm{H}} 7.13\left(\mathrm{t}, \mathrm{J}_{\mathrm{HH}}=6 \mathrm{~Hz}, 1 \mathrm{H}, \mathrm{Ar}-\mathrm{CH}\right) ; 7.35\left(\mathrm{~d}, \mathrm{~J}_{\mathrm{HH}}=7 \mathrm{~Hz}, 1 \mathrm{H}, \mathrm{Ar}-\mathrm{CH}\right) ; 7.39$ (pseudo-d, $\left.\mathrm{J}_{\mathrm{HH}}=6 \mathrm{~Hz}, 2 \mathrm{H}, \mathrm{Ar}-\mathrm{CH}\right) ; 7.55$ (pseudo-d, $\left.\mathrm{J}_{\mathrm{HH}}=6 \mathrm{~Hz}, 2 \mathrm{H}, \mathrm{Ar}-\mathrm{CH}\right) ; 7.66\left(\mathrm{~d}, \mathrm{~J}_{\mathrm{HH}}=8 \mathrm{~Hz}, 2 \mathrm{H}, \mathrm{Ar}-\mathrm{CH}\right.$ ); 7.75 $\left(\mathrm{t}, \mathrm{J}_{\mathrm{HH}}=8 \mathrm{~Hz}, 2 \mathrm{H}, \mathrm{Ar}-\mathrm{CH}\right) ; 7.92\left(\mathrm{~d}, \mathrm{~J}_{\mathrm{HH}}=8 \mathrm{~Hz}, 1 \mathrm{H}, \mathrm{Ar}-\mathrm{CH}\right) ; 8.36(\mathrm{~d}, \mathrm{JHH}=8 \mathrm{~Hz}, 1 \mathrm{H}, \mathrm{Ar}-\mathrm{CH}) ; 8.72\left(\mathrm{~d}, \mathrm{~J}_{\mathrm{HH}}=8 \mathrm{~Hz}\right.$, $1 \mathrm{H}, \mathrm{Ar}-\mathrm{CH}) ; 9.24,13.24(2 \mathrm{x} \mathrm{s}, 1 \mathrm{H}, \mathrm{NH}) ;{ }^{13} \mathrm{C} \mathrm{NMR}\left(100.61 \mathrm{MHz}, \mathrm{CDCl}_{3}\right): \delta_{\mathrm{C}} 116.5,121.4,127.3,127.8,128.3$, 128.6, 129.1, 130.1, 138.4, 139.3, 146.6, 147.5, 151.1 (13 x s, Ar); 166.1 (s, C=O); 177.3 (s, C=S); Elemental analysis for $\mathrm{C}_{19} \mathrm{H}_{15} \mathrm{~N}_{3} \mathrm{OS}$ : [Found (Calculated.)]: $\mathrm{C}=69.12$ (68.45); $\mathrm{H}=4.73(4.53) ; \mathrm{N}=12.55$ (12.60); $\mathrm{S}=9.96$ (9.62).

\section{Synthesis of $N$-pyridyl- $N$ '-(3,5-dimethyoxybenzoyl)thiourea (L2)}

Yielding pale yellow crystalline solid (64\% yield), $\mathbf{L} 2$ was prepared from 3,5-dimethoxybenzoyl chloride (1.51 g, $7.51 \mathrm{mmol})$, ammonium thiocyanate $(0.57 \mathrm{~g}, 7.51 \mathrm{mmol})$, and 2-aminopyridine $(0.71 \mathrm{~g}, 7.51 \mathrm{mmol})$ in the same manner as described in L1. ${ }^{1} \mathrm{H}$ NMR $\left(400.11 \mathrm{MHz}, \mathrm{CDCl}_{3}\right)$ : $\delta_{\mathrm{H}} 3.80\left(\mathrm{~s}, 6 \mathrm{H}, \mathrm{OCH}_{3}\right) ; 6.62\left(\mathrm{t}, \mathrm{J}_{\mathrm{HH}}=4 \mathrm{~Hz}, 1 \mathrm{H}, \mathrm{Ar}-\right.$ $\mathrm{CH}) ; 6.10\left(\mathrm{~d}, \mathrm{~J}_{\mathrm{HH}}=2 \mathrm{~Hz}, 1 \mathrm{H}, \mathrm{Ar}-\mathrm{CH}\right) ; 7.84\left(\mathrm{t}, \mathrm{J}_{\mathrm{HH}}=8 \mathrm{~Hz}, 1 \mathrm{H}, \mathrm{Ar}-\mathrm{CH}\right) ; 8.34\left(\mathrm{~d}, \mathrm{~J}_{\mathrm{HH}}=6 \mathrm{~Hz}, 1 \mathrm{H}, \mathrm{Ar}-\mathrm{CH}\right) ; 8.67(\mathrm{~d}$, $\left.\mathrm{J}_{\mathrm{HH}}=8 \mathrm{~Hz}, 1 \mathrm{H}, \mathrm{Ar}-\mathrm{CH}\right) ; 9.48,13.47(2 \mathrm{x} \mathrm{s}, 1 \mathrm{H}, \mathrm{NH}) ;{ }^{13} \mathrm{C} \mathrm{NMR}\left(100.61 \mathrm{MHz}, \mathrm{CDCl}_{3}\right): \delta_{\mathrm{C}} 55.8\left(\mathrm{~s}, \mathrm{OCH}_{3}\right) ; 105.6$, 106.0, 116.9, 121.4, 139.7, 150.6, $161.3(8 \times \mathrm{s}, \mathrm{Ar}-\mathrm{CH}) ; 166.1(\mathrm{~s}, \mathrm{C}=\mathrm{O}) ; 177.5$ (s, C=S); Elemental analysis for $\mathrm{C}_{15} \mathrm{H}_{15} \mathrm{~N}_{3} \mathrm{OS}$ : [Found (Calculated.)]: $\mathrm{C}=56.98$ (56.77); $\mathrm{H}=4.94$ (4.76); $\mathrm{N}=13.21$ (13.24); $\mathrm{S}=10.68$ (10.10).

\section{Preparation of film membranes}

A solution of polyvinyl chloride (PVC) powder $(120 \mathrm{mg})$, sodium tetraphenylborate $(1.5 \mathrm{mg})$, tributylphosphate (240 mg), and of the compound (L1 and L2) $(80 \mathrm{mg}$ ) were dissolved in tetrahydrofuran (THF) with vigorous stirring for $c a$. 6 hours until the solution became a homogenous viscous solution [9]. The resulting solution was then transferred onto a glass slide of $5 \mathrm{~cm}$ x $0.5 \mathrm{~cm}$ which was placed in a SCS 6808 Spin Coater. The substrate was spun at high speed (2500 rpm) to obtain smooth and homogenous thin film.

\section{Preparation for $\mathrm{pH}$ studies}

The study was carried out in $\mathrm{pH}$ buffered solution to minimise any change in $\mathrm{pH}$ due to the effects of temperature, light and the presence of carbon dioxide gas in air which can produce errors in the results. In this study, $1 \mathrm{~mL}$ of $5 \mathrm{x}$ $10^{-4} \mathrm{M}$ of $\mathrm{Cu}(\mathrm{II})$ ion solution was added to $5 \mathrm{ml}$ of $5 \times 10^{-5} \mathrm{M}$ solutions of $\mathbf{L 1}$ and $\mathbf{L 2}$ prepared in different $\mathrm{pH}$ buffers ( $\mathrm{pH}$ range from 3 to 10). A sample of the mixture was transferred into $1 \mathrm{~cm}^{3}$ cuvette and the spectral 
properties of these samples were recorded via UV-vis spectroscopy. Collected data was plotted to study effect of $\mathrm{pH}$ on response of $\mathbf{L 1}$ and $\mathbf{L} 2$ to sense the presence of $\mathrm{Cu}$ (II) ion.

\section{Synthesis and characterisation of pyridine-thiourea}

\section{Results and Discussion}

The pyridine-thiourea derivatives are proposed as ionophores (Figure 1) have their own advantages such as exhibit quick and ease of synthesis and purification. Scheme 1 shows the general synthetic work-up of the pyridine-thiourea derivatives synthesis. The molecular system featuring electron donating molecular framework has ability to increase their electron density throughout the molecular system, a desired feature to promote the binding ability of the ionophores with $\mathrm{Cu}$ (II) ion. Besides, $\mathbf{L 1}$ and $\mathbf{L 2}$ theoretically have known as multidentate ligand due to the existence of different coordination sites $(\mathrm{N}, \mathrm{O}$, and $\mathrm{S}$ ) in particular geometry. Good yield of synthesised compounds were obtained of $73 \%$, and $89 \%$ for $\mathbf{L 1}$ and $\mathbf{L} \mathbf{2}$ respectively.

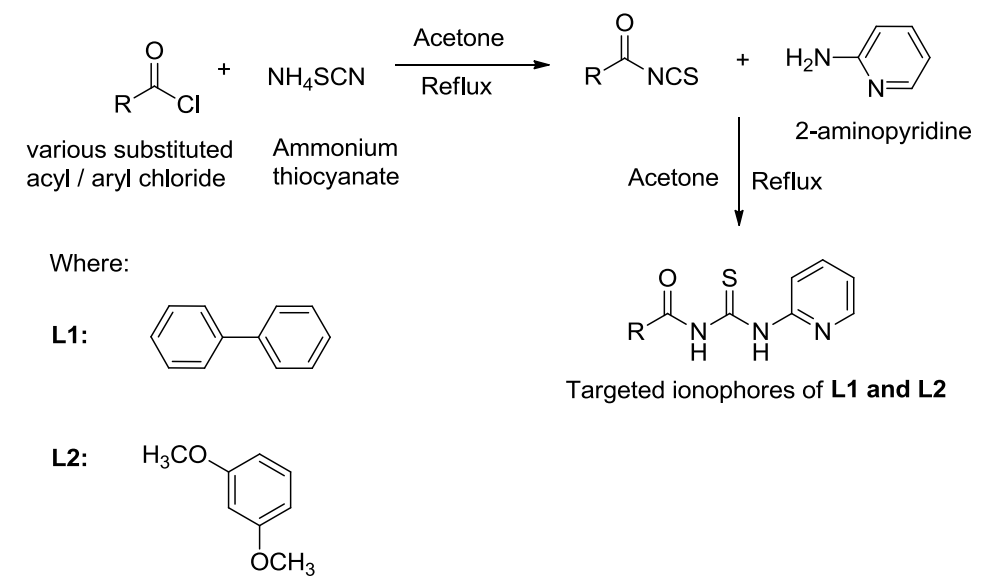

Scheme 1. The general synthetic work-up of ionophores synthesis

The main IR bands of interest for $\mathbf{L} \mathbf{1}$ and $\mathbf{L} 2$ have been identified to show five absorption bands, namely, $v(\mathrm{~N}-\mathrm{H})$, $v(\mathrm{C}-\mathrm{H}), v(\mathrm{C}=\mathrm{O}), v(\mathrm{C}-\mathrm{N})$, and $v(\mathrm{C}=\mathrm{S})$. The first absorption band was assigned as the secondary amine $\mathrm{N}-\mathrm{H}$ which could be observed at 3259 to $3267 \mathrm{~cm}^{-1}$ as medium intensity absorption band which was in a good agreement with previous works carried out by $[10,11]$ who reported the N-H stretching band was located in similar region. In most thiourea derivatives, N-H stretching band appeared at above $3200 \mathrm{~cm}^{-1}$ due to the influence of strong intramolecular hydrogen bond between $\mathrm{N}-\mathrm{H} . . \mathrm{O}=\mathrm{C}[12,13]$ which led to the formation of broad and weak absorption band of $\mathrm{N}-\mathrm{H}$ stretching [14,15]. Meanwhile, C-H alkane stretching bands could be observed in the region of 2974 to $3064 \mathrm{~cm}^{-1}$ as aromatic and alkyl type of $\mathrm{CH}$ groups were present in their molecular structures. In addition, in a range of 1524 to $1536 \mathrm{~cm}^{-1}$, high intensity of $v(\mathrm{C}-\mathrm{N})$ absorption band clearly been observed. Strong absorption band observed at $1670 \mathrm{~cm}^{-1}$ in both spectra were assigned as $\mathrm{C}=\mathrm{O}$ absorption band. The appearance of the strong band was in a good agreement with previous studies carried out by [16 - 18]. The $\mathrm{C}=\mathrm{O}$ stretch in all synthesised compounds were found at lower wavenumber compared with expected carbonyl stretching at around $1700 \mathrm{~cm}^{-1}$ as most carbonyl thiourea derivatives were stabilised by formation intramolecular hydrogen bond of $\mathrm{C}=\mathrm{O} \ldots \mathrm{H}-\mathrm{N}$ which led to emergence of pseudo-six-membered ring [19]. Consequently, formation of the intramolecular hydrogen bond interaction led to an increase in its polarity making the double bond character to be weaker and shifting the band to a lower wavenumber region [20]. The absorption band of $\mathrm{C}=\mathrm{S}$ stretch for all synthesised compounds appeared as medium bands within range of 739 to $741 \mathrm{~cm}^{-1}$. The presence of intramolecular hydrogen bonding between $\mathrm{C}=\mathrm{O}$ with $\mathrm{N}-\mathrm{H}$ moiety led to stronger electronegativity property of the $\mathrm{N}-\mathrm{H}$ group which simultaneously enhanced double bond character of the $\mathrm{C}=\mathrm{S}$ group [21] in which was found by several researchers [12, 22, 23]. 
In the ${ }^{1} \mathrm{H}$ NMR spectrum of $\mathbf{L 2}$ a singlet resonance at $\delta_{\mathrm{H}} 3.80 \mathrm{ppm}$ was attributed to methoxy moiety in the compound. The $\mathrm{O}-\mathrm{CH}_{3}$ resonance was located at higher chemical as it was bonded to electronegative oxygen atom which pulled the electrons from proton methyl and deshielded the resonance to higher chemical shift region [24, 25]. High intensity singlet resonance with $6 \mathrm{H}$ integration shows that this resonance represents two symmetrical methoxy groups as reported by [26, 27]. The aromatic protons of both $\mathbf{L} \mathbf{1}$ and $\mathbf{L} \mathbf{2}$ can be observed at $\delta_{\mathrm{H}} 7.13-8.74$ ppm appeared as distinctive multiplet resonances due to the presence of unresolved aromatic protons [28]. The most common observation in ${ }^{1} \mathrm{H}$ NMR analysis of typical acyl thiourea molecular system is the presence of two singlet $\mathrm{N}-\mathrm{H}$ resonances at the most downfield position $[10,11]$. Both of these resonances were observed as distinctive broad singlets at the most deshielded region in the spectra. This is due to the presence of several electronwithdrawing moieties namely carbonyl and thiocarbonyl in the molecule which decreased electron density around the resonances and shifted the protons of $\mathrm{N}-\mathrm{H}$ to downfield position [17, 29]. However, carbonyl-substituted N-H proton (NHCO) was found to be at lower chemical shift $\left(\delta_{\mathrm{H}} 9.24-9.48 \mathrm{ppm}\right)$ in comparison to thione-substituted $\mathrm{N}$ $\mathrm{H}$ proton (NHCS) which is located at $\delta_{\mathrm{H}} 13.24-13.47 \mathrm{ppm}$ as the formation of intramolecular hydrogen bond between carbonyl moiety and thione-substituted $\mathrm{N}-\mathrm{H}$ resonance produced stronger deshielding effect $[12,15]$. Carbon resonances in ${ }^{13} \mathrm{C}$ NMR spectra of $\mathbf{L 2}$ could be observed at upfield position $\left(\delta_{\mathrm{C}} 55.8 \mathrm{ppm}\right)$ due to the presence of methyl moiety in molecular structure. However, $\mathrm{CH}_{3}$ resonance of $\mathbf{~} \mathbf{2}$ is observed at higher chemical shift $\left(\delta_{\mathrm{C}} 55.8 \mathrm{ppm}\right)$ as it was bonded to electronegative atom, oxygen, shifted the resonance to a higher chemical shift [30]. Resonances of aromatic carbon were observed at $\delta_{C}$ 105.5-161.2 ppm. Two distinctive resonances at the most downfield region $\left(\delta_{\mathrm{C}} 166.0\right.$ and $\left.177.3 \mathrm{ppm}\right)$ can be observed which corresponded to carbonyl $(\mathrm{C}=\mathrm{O})$ and thione $(\mathrm{C}=\mathrm{S})$ respectively in both spectra of $\mathbf{L} \mathbf{1}$ and $\mathbf{L} \mathbf{2}[16,31,32]$. This is due to formation of intramolecular hydrogen bonding and electronegativity effect of oxygen and sulphur atoms which pulled certain amount of electrons from both moieties and deshielded the resonances to higher chemical shift $[13,33]$. The existence of several important resonances at expected regions in ${ }^{1} \mathrm{H}$ and ${ }^{13} \mathrm{C}$ NMR spectra of all synthesised compounds proved that pyridine-thiourea derivatives of both $\mathbf{L} \mathbf{1}$ and $\mathbf{L} \mathbf{2}$ were successfully synthesised.

\section{Evaluation of sensing performances towards $\mathrm{Cu}$ (II) ion: Reaction responses}

The reaction of the films towards different concentration of $\mathrm{Cu}$ (II) ion was investigated. Figure 2 and Figure 3 show the reaction response of $\mathbf{L} \mathbf{1}$ and $\mathbf{L} \mathbf{2}$ in the presence of $\mathrm{Cu}$ (II) ion within concentration range of $\mathrm{Cu}$ (II) ion was $2 \times 10^{-4} \mathrm{M}$ to $10 \times 10^{-4} \mathrm{M}$. Upon exposure of $\mathrm{Cu}$ (II) ion to the film, the formation of absorption band of $\mathbf{L} \mathbf{1}$ towards $\mathrm{Cu}$ (II) ion observed at wavelength of $385 \mathrm{~nm}$. The higher the concentration of $\mathrm{Cu}$ (II) ion, higher the intensity of the absorption bands was observed. Similar observation was discovered in $\mathbf{L 2}$ film with formation of medium absorption shoulder bands when $\mathrm{Cu}$ (II) ion was introduced to the film.

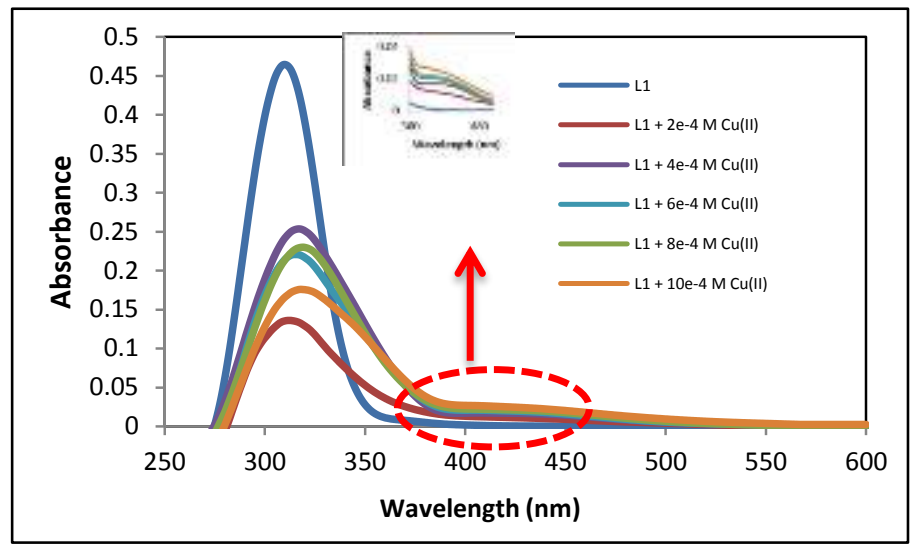

Figure 2. Reaction response of $\mathbf{L 1}$ towards $\mathrm{Cu}$ (II) ion 


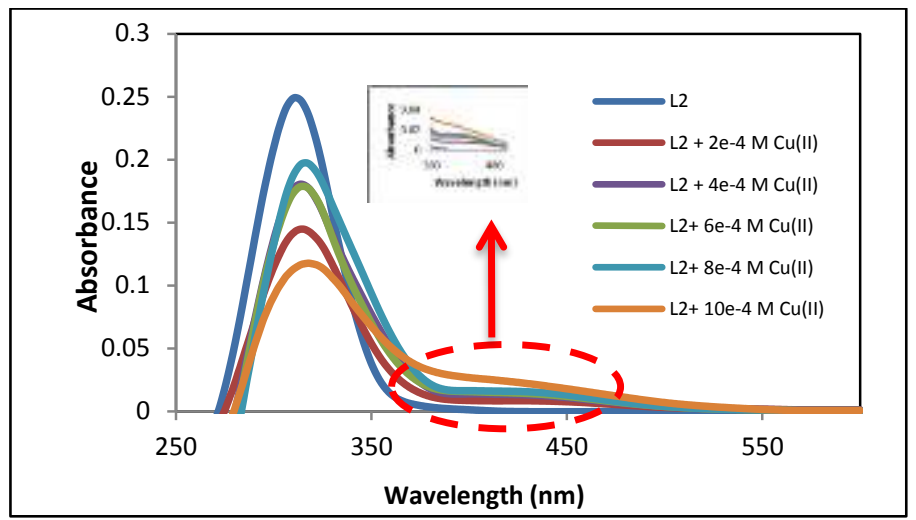

Figure 3. Reaction response of $\mathbf{L} \mathbf{2}$ towards $\mathrm{Cu}$ (II) ion

\section{Reproducibility of $\mathrm{L} 1$ and $\mathrm{L} 2$}

A reproducible film will produce a stable and consistent data which is very crucial aspect in the sensing application. A number of 8 strips of samples were fabricated and used to complete the reproducibility test. Figure 4 shows reproducibility data behaviour of $\mathbf{L} \mathbf{1}$ and $\mathbf{L} 2$.

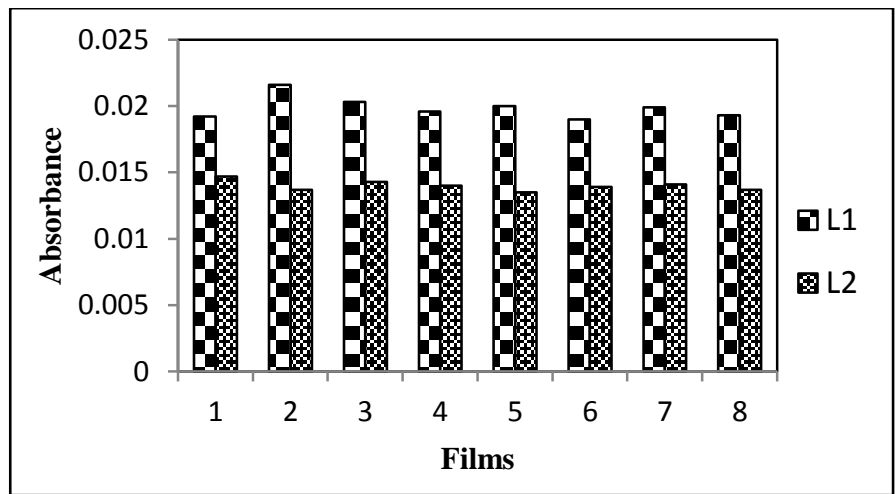

Figure 4. Graph of reproducibility studies for $\mathbf{L} \mathbf{1}$ and $\mathbf{L} 2$

Figure 4 indicates stable and consistent reading for all films. Thus, the consistency in reading of the film showed that all films exhibited high reproducibility ability. Relative standard deviation (RSD) was calculated to prove and compare which film system possessed the best reproducibility. Table 1 shows the RSD value of $\mathbf{L 1}$ and $\mathbf{L} 2$ for their reproducibility property.

Table 1. RSD value of reproducibility for $\mathbf{L} \mathbf{1}$ and $\mathbf{L} \mathbf{2}$

\begin{tabular}{lccc}
\hline Film & Average, $\mathbf{x}$ & Standard Deviation & Relative Standard Deviation (\%) \\
\hline L1 & 0.019863 & 0.000828 & 4.17 \\
L2 & 0.013988 & 0.000383 & 2.74 \\
\hline
\end{tabular}


Table 1 revealed both $\mathbf{L 1}$ and $\mathbf{L 2}$ exhibited low value of RSD which were 4.17\% and 2.74\% respectively in which indicates higher ability of reproducibility [34, 35]. Therefore, it can be concluded that both L1 and L2 films exhibited reproducible results for detection of $\mathrm{Cu}$ (II) ion which is critical in order to produce uniform and accurate reading in its sensing performance. L2 exhibits the most effective reproducibility compared to L1. Higher RSD value might be caused by several technical errors during preparation of thin film such as uncontrollable thickness as well as uniformity of the films and amount of compound trapped in the films.

\section{Regeneration of L1 and L2}

Regeneration of chemosensor represents the ability of the sensors to be used repeatedly. An ideal sensor is a sensor with high regeneration property in which it can be used repeatedly and effectively for several measurements. Figure 5 shows regeneration data of all designated chemosensor ( $\mathbf{L 1}$ and $\mathbf{L 2})$.

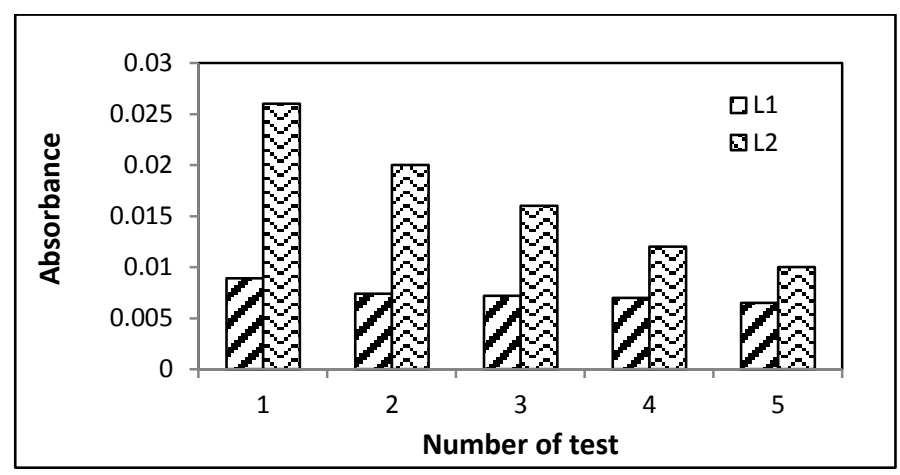

Figure 5. Graph of regeneration for $\mathbf{L} \mathbf{1}$ and $\mathbf{L} 2$

L1 found to have ideal regeneration pattern up to 5 cycles which indicated multi-testing films. However, the sensing performance of $\mathbf{L} \mathbf{2}$ decreased dramatically from the first to the fifth cycles compared to $\mathbf{L} \mathbf{1}$ which showed gradual decreasing of its sensing performance. Based on Figure 5, $\mathbf{L 1}$ offered ideal regeneration ability compared to $\mathbf{L 2}$. Table 2 shows the value of RSD in term of regeneration property of $\mathbf{L 1}$ and $\mathbf{L 2}$.

Table 2. RSD value of regeneration for $\mathbf{L} 1$ and $\mathbf{L 2}$

\begin{tabular}{llclc}
\hline Film Cycle & L1 & \multicolumn{3}{c}{ L2 } \\
\cline { 2 - 5 } & Absorbance & $\begin{array}{c}\text { Percentage of } \\
\text { regeneration } \\
(\mathbf{\%})\end{array}$ & Absorbance & $\begin{array}{c}\text { Percentage of } \\
\text { regeneration } \\
(\mathbf{\%})\end{array}$ \\
\hline 1 & 0.0089 & 100 & 0.026 & 100 \\
2 & 0.0074 & 83.15 & 0.020 & 76.92 \\
3 & 0.0072 & 80.90 & 0.016 & 61.54 \\
4 & 0.0070 & 78.65 & 0.012 & 46.15 \\
5 & 0.0065 & 73.03 & 0.010 & 38.46 \\
\hline Mean, $\mathrm{x}$ & 0.007400 & & 0.016800 & \\
\hline Standard & 0.000903 & & 0.006419 & \\
deviation $(\sigma)$ & & & 38.21 & \\
\hline RSD $(\%)$ & 12.20 & & & \\
\hline
\end{tabular}


The huge decrease of absorbance for both $\mathbf{L 1}$ and $\mathbf{L 2}$ films was contributed by the second cycle. This is due to the film which was used directly after fabrication process without any cleaning process to remove untrapped residue of the compound which led to involvement of the untrapped residue in the sensing mechanism. L1 exhibits the lowest RSD value with $12.20 \%$ compared to $\mathbf{L} 2$ with $38.21 \%$. Large value of RSD for $\mathbf{L} \mathbf{2}$ contributed from the leaching of compound from the film during the metal ion leaching process in EDTA solution which reduced the amount of compound to detect $\mathrm{Cu}$ (II) ion leading to lower sensing response in the following cycles. This is due to the strength of EDTA to bind to $\mathrm{Cu}$ (II) ion and unsurprisingly, it is also able to attract the compound-Cu(II) complex from the film. Besides, due to the unbounded compounds in the film on the glass substrate, the compounds were easily detached and leached off when the film became swollen during the sensing studies.

\section{Limit of Detection (LOD)}

In this respect, LOD of $\mathbf{L 1}$ and $\mathbf{L 2}$ films towards $\mathbf{C u}$ (II) ion was carried out to investigate the efficiency and sensitivity of the sensors for $\mathrm{Cu}$ (II) detection which was calculated using Equation 1. Figure 6 shows the LOD graph of $\mathbf{L} \mathbf{1}$ and $\mathbf{L} \mathbf{2}$.

$$
L O D=\frac{3 s}{\sigma}
$$

where $s$ is the standard deviation for the blank and $\sigma$ is the slope of the LOD graph.

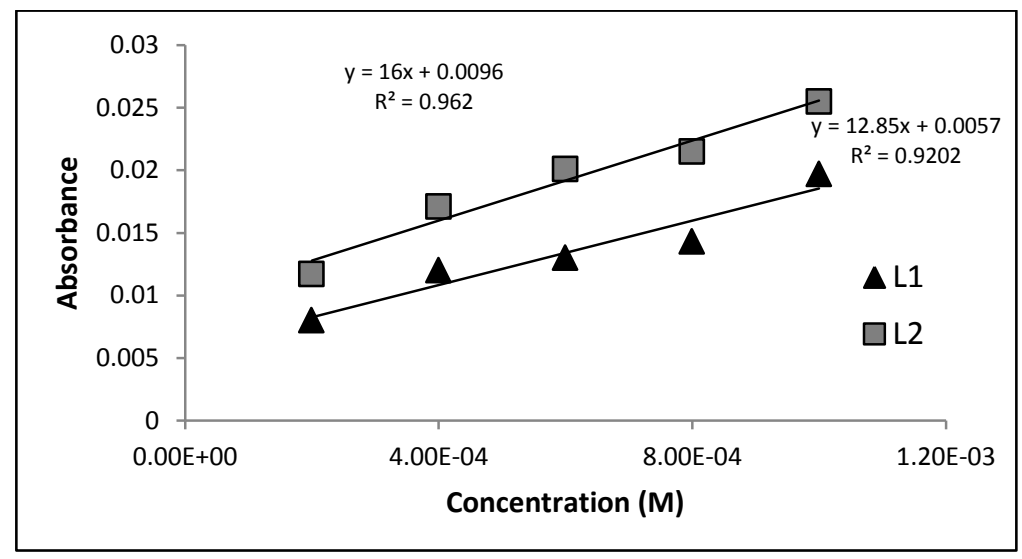

Figure 6. Calibration curves for LOD of $\mathbf{L 1}$ and $\mathbf{L} 2$

LOD results revealed that, $\mathbf{L 1}$ shows higher sensitivity towards detection of $\mathbf{C u}$ (II) ion compared to $\mathbf{L} 2$. These experimental results were in good agreement with the theoretical investigation which $\mathbf{L} 1$ exhibits higher response towards $\mathrm{Cu}$ (II) ion. In contrast, $\mathbf{L} \mathbf{2}$ shows lowest sensitivity towards $\mathrm{Cu}$ (II) ion which was initially proven in the theoretical study on its binding mechanism and low interaction energy of $\mathbf{L 2}$ towards $\mathbf{C u}$ (II). Table 3 shows the data of LOD analysis of $\mathbf{L 1}$ and $\mathbf{L} \mathbf{2}$.

Table 3. The data of LOD for $\mathbf{L} 1$ and $\mathbf{L 2}$

\begin{tabular}{lcc}
\hline Film & L1 & L2 \\
\hline$\sigma$ & 12.85 & 16.00 \\
$\mathrm{~s}$ & $5.76 \times 10^{-5}$ & $7.87 \times 10^{-5}$ \\
LOD $(\mathrm{M})$ & $1.34 \times 10^{-5}$ & $1.48 \times 10^{-5}$ \\
\hline \multicolumn{2}{l}{$\sigma=$ slope of LOD graph; $s=$ standard deviation }
\end{tabular}




\section{pH Effect}

The reaction of metals with ligands is $\mathrm{pH}$ dependence. Therefore, $\mathrm{pH}$ study was carried out to find optimum $\mathrm{pH}$ condition for the reaction of $\mathrm{Cu}$ (II) ion with the selected compounds ( $\mathbf{L 1}$ and L2) which was carried out in the range $\mathrm{pH} 2$ to $\mathrm{pH} 9$. Figure 7 illustrates the effect of $\mathrm{pH}$ in the metal-ligand sensing performance.

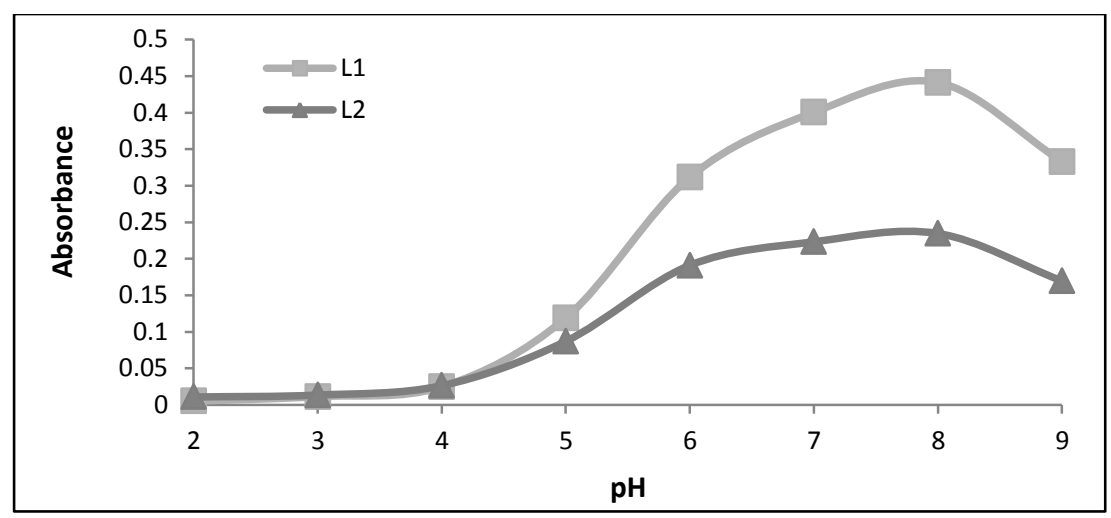

Figure 7. $\mathrm{pH}$ effect for metal-ligand sensing performance of $\mathbf{L} \mathbf{1}$ and $\mathbf{L} \mathbf{2}$

Result obtained revealed that $\mathbf{L 1}$ and $\mathbf{L 2}$ showed quite similar patterns in the $\mathrm{pH}$ dependent graph which the curve started to increase at $\mathrm{pH} 4$ then declined at $\mathrm{pH}$ 9. The most optimum $\mathrm{pH}$ for $\mathbf{L} \mathbf{1}$ and $\mathbf{L} \mathbf{2}$ compounds to sense $\mathrm{Cu}$ (II) ion was found at $\mathrm{pH}$ 8. This is due to the existence of intensive competition between $\mathrm{H}^{+}$and $\mathrm{Cu}$ (II) which decreased the ability of the compounds to form interaction with the metal ion resulting in lower response of absorbance at highly acidic condition [36]. Consequently, the absorbance of the compound-Cu (II) complex increased with increasing $\mathrm{pH}$ value.

\section{Density functional theory (DFT) analysis}

The ability of $\mathbf{L 1}$ and $\mathbf{L 2}$ to interact with $\mathrm{Cu}$ (II) was proven via density functional theory (DFT) analysis. Based on the analysis, $\mathbf{L} 1$ and $\mathbf{L} 2$ possessed ability to interact with the metal ion via $C=O$ and $C=S$ which acting as chelating ligand [37, 38]. Chelating behaviour of a ligand is known to have better and stronger interaction to enhance sensing performance of chemosensor. Similar binding behaviour observed in both $\mathbf{L 1}$ and $\mathbf{L} \mathbf{2}$ due to the presence of thiourea moiety in their molecular frameworks which is much dominant than other possible binding sites in the molecules. Based on the theoretical study, nitrogen atom of pyridine found to be twisted away from the interaction area which proved the pyridine portion was not involved in the interaction. There were several parameters which were taken into consideration in this analysis to compare capability of the compounds to interact towards $\mathrm{Cu}$ (II) such as interaction distance and binding energy. In term of interaction distance, $\mathbf{L} \mathbf{1}$ indicated the lowest distance compared to $\mathbf{L 2}$. The interaction distance of $\mathbf{L 1}$ via $\mathrm{C}=\mathrm{O}$ and $\mathrm{C}=\mathrm{S}$ towards $\mathrm{Cu}$ (II) are $2.027 \AA$ and $2.520 \AA$ respectively. The obtained distances were in the same region as reported by [31, 39]. This showed that $\mathbf{L} \mathbf{1}$ has the highest strength to bind with $\mathrm{Cu}^{2+}$ followed by $\mathbf{L 2}$. Furthermore, in term of binding energy, the most negative value indicates optimum stability and strength of the interaction [40]. L1 exhibits the most negative value of interaction energy (-230.34 $\mathrm{kJ} / \mathrm{mol}$ ) compared to $\mathbf{L} \mathbf{2}-227.34 \mathrm{~kJ} / \mathrm{mol}$. The stronger binding energy and the shorter interaction distance of $\mathbf{L} \mathbf{1}$ was caused by the stronger electron donating effect of biphenyl than 3,5-dimethoxybenzene groups in L2. Table 4 shows details on the theoretical evaluation data of these compounds via Gaussian 09 analysis.

Table 4. Theoretical interaction study between $\mathbf{L 1}$ and $\mathbf{L 2}$ towards $\mathrm{Cu}^{2+}$

\begin{tabular}{llll}
\hline Compound & $\mathbf{C}=\mathbf{O} \cdots \mathbf{C u}(\stackrel{\AA}{)})$ & $\mathbf{C}=\mathbf{S}^{\cdots} \mathbf{C u}(\AA)$ & Binding Energy $(\mathbf{k J} / \mathbf{m o l})$ \\
\hline L1 & 2.027 & 2.520 & -230.34 \\
L2 & 2.030 & 2.523 & -227.34 \\
\hline
\end{tabular}




\section{Conclusion}

On the basis of the results discussed in this paper, two new pyridine-thiourea derivatives $\mathbf{L} \mathbf{1}$ and $\mathbf{L} \mathbf{2}$ have been successfully synthesised and characterised prior to form active ionophores film entrapped in a PVC matrix for detection of $\mathrm{Cu}$ (II) ion. The reaction response of the ionophores towards different $\mathrm{Cu}$ (II) ion concentration was observed via difference in spectral features upon interaction with $\mathrm{Cu}(\mathrm{II})$. Apparently, $\mathbf{L 1}$ exhibited good response with high sensitivity towards $\mathrm{Cu}$ (II) ion with limit of detection $1.34 \times 10^{-5} \mathrm{M}$ which was in good agreement with theoretical calculations. In fact, the theoretical analysis proved the oxygen $(\mathrm{O})$ atom mainly defines its reactive site compared to sulphur $(\mathrm{S})$ atom. Whilst, nitrogen $(\mathrm{N})$ atom on pyridine moiety found to be twisted away from the interaction area; therefore, pyridine portion does not involved in the interaction mechanism with $\mathrm{Cu}$ (II). In addition, $\mathbf{L 1}$ offered ideal interaction and binding energy for $\mathrm{Cu}$ (II) sensing $(2.027$ and $-230.34 \mathrm{~kJ} / \mathrm{mol})$. In conclusion, a novel approach involving single molecular system of pyridine-thiourea (L1 and L2) exhibited promising ability and potential for $\mathrm{Cu}$ (II) detection.

\section{Acknowledgement}

The authors would like to acknowledge the Ministry of Education (MOE) for the postgraduate student's scholarship (MyBrain15), and the School of Fundamental Science, Universiti Malaysia Terengganu for the research support and facilities.

\section{References}

1. Kaya, E. D., Söyüt, H. and Sükrü, B. (2013). Carbonic anhydrase activity from the gilthead sea bream (Sparus aurata) liver: The toxicological effects of heavy metals. Environmental Toxicology and Pharmacology, 36: 514 $-521$.

2. Olawoyin, R., Oyewole, S. A. and Grayson, R. L. (2012). Potential risk effect from elevated levels of soil heavy metals on human health in the Niger delta. Ecotoxicology and Environmental Safety, 85: 120 - 130.

3. Viswanathan, K. (2012). Utilizing a tripeptide conjugated fluorescent hybrid nanoparticles as a fluorescence sensor for the determination of copper ions. Sensors and Actuators A, 175: $15-18$.

4. Lin, Q., Chen, P., Liu, J., Fu, Y-P., Zhang, Y-M. and Wei, T-B. (2013). Colorimetric chemosensor and test kit for detection copper (II) cations in aqueous solution with specific selectivity and high sensitivity. Dyes and Pigments, 98: $100-105$.

5. Aziz, H. A., Adlan, M. N. and Ariffin, K. S. (2008). Heavy metals (Cd, Pb, $\mathrm{Zn}, \mathrm{Ni}, \mathrm{Cu}, \mathrm{Cr}$ (III)) removal from water in Malaysia: Post treatment by high quality limestone. Bioresource Technology, 99: 1578 -1583.

6. Bridgeman, J., Baker, A., Brown, D. and Boxall, J. B. (2015). Portable LED fluorescence instrumentation for the rapid assessment of potable water quality. Science of the Total Environment, 524: 338 -346.

7. Firooz, A. L., Ensafi, A. A., Karimi, K. and Khalifeh, R. (2013). Specific sensing of mercury (II) ions by an optical sensor based on a recently synthesized ionophore. Sensors and Actuator B, 185: 84 - 90.

8. Pradeep, T. (2009). Noble metal nanoparticles for water purification: a critical review. Thin Solid Films. 517(24): $6441-6478$.

9. Bakker E, Simon W. (1992). Selectivity of ion-sensitive bulk optodes. Analytical Chemistry, 64(17):1805 1812.

10. Saeed, A., Shaheen, U., Hameed, A. and Naqvi, S. Z. H. (2009). Synthesis, characterization and antimicrobial activity of some new 1-(fluorobenzoyl)-3-(fluorophenyl)thioureas. Journal of Fluorine Chemistry, 130: 1028 1034.

11. Duan, X. -E., Wei, X. -H., Tong, H. -B., Bai, S. -D., Zhang, Y. -B. and Liu, D. -S. (2011). Ferrocenemodified pyrimidinyl acyl-thiourea derivatives: Synthesis, structures and electrochemistry. Journal of Molecular Structure, 1005: 91 - 99.

12. Karipcin, F., Atis, M., Sariboga, B., Celik, H. and Tas, M. (2013). Structural, spectral, optical and antimicrobial properties of synthesized 1-benzoyl-3-furan-2-ylmethyl-thiourea. Journal of Molecular Structure, 1048: 69 77.

13. Arslan, N. B., Kazak, C. and Aydın, F. (2012). N-(4-nitrobenzoyl)-N'-(1,5-dimethyl-3-oxo-2-phenyl-1H$3(2 \mathrm{H})$-pyrazolyl)-thiourea hydrate: synthesis, spectroscopic characterization, X-ray structure and DFT studies. Spectrochimica Acta Part A-Molecular and Biomolecular Spectroscopy, 89: 30-38. 
14. Rahamathullah, R., Khairul, W. M., Salleh, H., Adli, H. K., Isa, M. I. N. and Tay, M. G. (2013). Synthesis. Characterization and Electrochemical Analysis of V-Shaped Disubstituted Thiourea-Chlorophyll Thin Film as Active Layer in Organic Solar Cells. International Journal of Electrochemical Science, 8: 3333 - 3348.

15. Zhang, L. -Y., Yuan, Y. -F., Hu, A. -G., Wang, J. -T. and Sun, J. (2001). Synthesis and molecular structure of a novel ferrocene-containing macrocyclic acyl thiourea derivative. Journal of Organometallic Chemistry, 637 639: $204-208$.

16. Saeed, A., Erben, M. F., Abbas, N. and Flörke, U. (2010). Synthesis, crystal X-ray diffraction structure, vibrational properties and quantum chemical calculations on 1-(4-(4-Fluorobenzamido)phenyl)-3-(4fluorobenzoyl)thiourea. Journal of Molecular Structure, 984: 240 - 245.

17. Tan, S. S., Al-abbasi, A. A., Mohamed Tahir, M. I. and Kassim, M. B. (2014). Synthesis, structure and spectroscopic properties of cobalt(III) complexes with 1-benzoyl-(3,3-disubstituted)thiourea. Polyhedron, 68: 287-294.

18. Atiş, M., Karicin, F., Sariboga, B., Tas, M. and Celik, H. (2012). Structural, antimicrobial and computational characterization of 1-benzoyl-3-(5-chloro-2-hydroxyphenyl)thiourea. Spectrochimica Acta Part A-Molecular and Biomolecular Spectroscopy, 98: 290 - 301.

19. Saeed, A., Erben, M. F. and Bolte, M. (2013). Synthesis, structural and vibrational properties of 1-(adamantine1-carbonyl)-3-halophenyl thioureas. Spectrochimica Acta Part A-Molecular and Biomolecular Spectroscopy, 102: $408-413$.

20. Koca, İ., Özgür, A., Coşkun, K. A. and Tutar, Y. (2013). Synthesis and anticancer activity of acyl thioureas bearing pyrazole moiety. Bioorganic \& Medicinal Chemistry, 21(13), $3859-3865$.

21. Estévez-Hernández, O., Otazo-Sánchez, E., Hidalgo-Hidalgo de Cisneros, J. L., Naranjo-Rodríguez, I., and Reguera, E. (2005). A Raman and infrared study of 1-furoyl-3-monosubstituted and 3,3-disubstituted thioureas. Spectrochimica Acta Part A-Molecular and Biomolecular Spectroscopy, 62(4-5): 964 -971.

22. Vinithra, G., Suganya, S. and Velmathi, S. (2013). Naked eye sensing of anions using thiourea based chemosensors with real time application. Tetrahedron Letter, 54(41): 5612 -5615.

23. Khairul, W. M., Yusof, M. F., Rahamathullah, R., Daud, A. I., Jasman, S. M., Hasan, M. F. A., Salleh, H., Adli, H. K. and Tay, M. G. (2013). Single Molecule Thin Film Featuring Disubstituted Thiourea (TU) Doped with Chlorophyll as Potential Active Layer in Photovoltaic Cell. International Journal of Electrochemical Science, 8: $8175-8190$.

24. Farhan, H. M. (2014). Preparation and investigation of complexes (bisazo)-imidazole with Co (II) and $\mathrm{Cu}$ (II). World Science Research Journals, 2(2): 26 - 34.

25. Hasali, N. H. M., Omar, M. N., Zuberdi, A. M. and AlFarra, H. Y. (2013). Biotransformation of ethyl pmethoxycinnamate from Kaempferia galanga L. using Aspergillus niger. International Journal of Bioscience, 3(7): $148-155$.

26. Koleva, B. B., Kolev, T., Lamshöft, M., Mayer-Figge, H., Sheldrick, W. S. and Spiteller, M. (2009). Synthesis, spectroscopic and structural elucidation of 1-butyl-4-[2-(3,5-dimethoxy-4-hydroxyphenyl)ethenyl)]pyridinium chloride tetrahydrate. Spectrochimica Acta Part A-Molecular and Biomolecular Spectroscopy, 74(5): 1120 1126.

27. Sinha, S., Mandal, B. and Chandrasekaran, S. (2000). Selective para metalation of unprotected 3-methoxy and 3 , 5-dimethoxy benzoic acids with n- butyl lithium - potassium tert -butoxide ( LIC - KOR ): Synthesis of 3, 5dimethoxy-4-methyl benzoic acid. Tetrahedron Letter, 41: 3157-3160.

28. Yusof, M. S. M., Jusoh, R. H., Khairul, W. M. and Yamin, B. M. (2010). Synthesis and characterisation a series of N-(3,4-dichlorophenyl)-N'-(2,3 and 4-methylbenzoyl) thiourea derivatives. Journal of Molecular Structure, 975(1-3): $280-284$.

29. Aydın, M., Ünal, B., Esat, B., Baykal, a., Karaoğlu, E., Toprak, M. S. and Sözeri, H. (2012). Synthesis, magnetic and electrical characteristics of poly(2-thiophen-3-yl-malonic acid)/Fe3O4 nanocomposite. Journal of Alloys and Compounds, 514: 45 - 53.

30. Zhang, X. H., Wang, L. Y., Zhan, Y. H., Fu, Y. I., Zhai, G. H. and Wen, Z. Y. (2011). Synthesis and structural studies of 4-[(5-methoxy-1H-indole-3-yl)-methylene]-3-methyl-isoxazole-5-one by X-ray crystallography, NMR spectroscopy, and DFT calculations. Journal of Molecular Structure, 994: 371 -378. 
31. Koch, K. R., Hallale, O., Bourne, S. A., Miller, J. and Basca, J. (2001). Self-assembly of 2:2 metallomacrocyclic complexes of $\mathrm{Ni}(\mathrm{II})$ and $\mathrm{Pd}(\mathrm{II})$ with 3,3,3',3'-tetraalkyl-1,1'-isophthaloylbis(thioureas). Crystal and molecular structures of cis- $\left[\mathrm{Pd}\left(\mathrm{L}_{2}-\mathrm{S}, \mathrm{O}\right)\right]_{2}$ and the adducts of the corresponding $\mathrm{Ni}(\mathrm{II})$ complexes: $\left[\mathrm{Ni}\left(\mathrm{L}^{1}-\mathrm{S}, \mathrm{O}\right)(\text { pyridine })_{2}\right]_{2}$ and $\left[\mathrm{Ni}\left(\mathrm{L}^{1}-\mathrm{S}, \mathrm{O}\right)(4-\text { dimethylaminopyridine })_{2}\right]_{2}$. Journal of Molecular Structure, 561 : $185-196$.

32. Marquez, H., Loupy, A., Calderon, O. and Pérez, E. R. (2006). An eco-friendly protocol for synthesis of thiourea derivatives: 1-benzoyl-3-benzylguanidine and 1-benzoyl-3-benzyl-O-ethylisourea. A possible nonpurely thermal microwave assisted reaction. Tetrahedron, 62(11): 2616 - 2621.

33. Khairul, W. M., Isa, M. I. N., Samsudin, A. S., Adli, H. K. and Ghazali, S. R. (2014). Conductive biodegradable film of N-octyloxyphenyl-N'-(4-methylbenzoyl)thiourea. Bulletin of Material Science, 37(2): $357-369$.

34. Jain, P. S., Khatal, R. N. and Surana, S. J. (2011). Spectrophotometric Determination of Amodiquine in Bulk and in Pharmaceutical Formulation. Research Journal of Pharmaceutical, Biological and Chemical Sciences, 2: $120-127$.

35. Rohini, P., Madhusudhanareddy, I., Gupta, A., Lokeswara, B. V. and Sundharani, G. (2011). Method development and validation for estimation of nevirapine from tablets by RP-HPLC. International Journal of Pharmaceutics, 1(1): 29-33.

36. Wilson, D., Arada, M. d. 1. A., Alegret, S. and del Valle, M. (2010). Lead (II) ion selective electrodes with PVC membranes based on two bis-thioureas as ionophore: 1,3-bis(N'-benzoylthioureido)benzene and 1,3-bis(N'furoylthioureido)benzene. Journal of Hazardous Material, 181: 140 -146.

37. Zhang, Y. -M., Pang, H. -X., Cao, C. and Wei, T.-B. (2007). Synthesis, crystal structure and biological activity of a new complex, + bis (1,1-diethyl-3-(3-fluorobenzoyl)-thiourea)nickel(II). Indian Journal of Chemistry Section A-Inorganic Bio-Inorganic Physical Theoretical \& Analytical Chemistry, 46A: 1787 - 1791.

38. Jadhao, S. Z. and Rathod, M. S. (2012). Synthesis and Structural Investigation of Zinc Metal-Ligand (Thiourea Derivative) Complexes. Journal of Chemical and Pharmaceutical Research, 4(3): 1562 -1565.

39. Schwade, V. D., Kirsten, L., Hagenbach, A., Lang E. S. and Abram, U. (2013). Indium (III), lead (II), gold (I) and copper (II) complexes with isophthaloylbis(thiourea) ligands. Polyhedron, 55: 155 -161.

40. Kumar, A., Kumar, V., Diwan, U. and Upadhyay, K. K. (2013). Highly sensitive and selective naked-eye detection of $\mathrm{Cu} 2+$ in aqueous medium by a ninhydrin-quinoxaline derivative. Sensors and Actuator B, 176: 420 $-427$. 